\title{
Transcription Coactivator Gene
}

National Cancer Institute

\section{Source}

National Cancer Institute. Transcription Coactivator Gene. NCI Thesaurus. Code C20673.

RNA polymerase II transcription of Class II genes involves the TFIID transcription complex comprised of general factors, including TBP, TFIIA, TFIIB, TFIID, TFIIE, TFIIF, TFIIG/J, and TFIIH, as well as gene-specific factors that include TAFs, which interact with regulatory protein activation domains to enhance transcription. A second group of cofactors includes PC1, PC2, and PC3, which have a strong positive influence on transcription. The combined action of general and gene-specific regulators encoded by Transcription Coactivator Genes enhances gene expression. ( $\mathrm{NCl}$ ) 